University of Nebraska - Lincoln

DigitalCommons@University of Nebraska - Lincoln

1988

\title{
SUGGESTIONS REGARDING ALCOHOLIC BIRD COLLECTIONS
}

Peter F. Cannell

Smithsonian Institution

Murray R. Bakst

Agricultural Research Service-U.S.D.A

Cheryl S. Asa

Winthrop College

Follow this and additional works at: https://digitalcommons.unl.edu/usdaarsfacpub

Part of the Agricultural Science Commons

Cannell, Peter F.; Bakst, Murray R.; and Asa, Cheryl S., "SUGGESTIONS REGARDING ALCOHOLIC BIRD COLLECTIONS" (1988). Publications from USDA-ARS / UNL Faculty. 620.

https://digitalcommons.unl.edu/usdaarsfacpub/620

This Article is brought to you for free and open access by the U.S. Department of Agriculture: Agricultural Research Service, Lincoln, Nebraska at DigitalCommons@University of Nebraska - Lincoln. It has been accepted for inclusion in Publications from USDA-ARS / UNL Faculty by an authorized administrator of DigitalCommons@University of Nebraska - Lincoln. 


\title{
SUGGESTIONS REGARDING ALCOHOLIC BIRD COLLECTIONS ${ }^{1}$
}

\author{
Peter F. CANnell \\ Division of Birds, National Museum of Natural History, Smithsonian Institution, \\ Washington, DC 20560 \\ MurRay R. BaKst \\ Agricultural Research Service-U.S.D.A., Avian Physiology Laboratory, \\ Beltsville, MD 20705
}

Cheryl S. Asa ${ }^{2}$

The Population Council, New York, NY 10021, and

The New York Zoological Society, Bronx, NY 10460

Keywords: Museology; collection management; fluid specimens; spirit specimens; alcoholic specimens; fixation; preservation.

One third of the known species of birds are unrepresented in alcoholic collections and nearly $70 \%$ of the rest are represented by 10 or fewer specimens (Wood et al. 1982, Zusi et al. 1982). Simply put, "existing anatomical specimens do not meet present and future research needs and . . . the situation must be corrected" (Jenkinson and Wood 1985:587).

Actually, current alcoholic specimen resources may be even worse than indicated by Wood et al. (1982), despite commendable recent improvements. Here, we argue the urgent need for additional alcoholic specimens, stressing in particular quality of fixation, the importance of series, documentation of treatment history, and the role of object conservators in the biological museum environment. Biological collection management lags behind that of art, anthropological, and historical collections. For the sake of a fundamental and irreplaceable ornithological resource, we urge that this gap be closed.

\section{UTILITY OF CURRENT SPECIMENS}

The limitations of existing alcoholic collections came to our attention during a comparative examination of avian reproductive anatomy. We dissected 13 specimens (representing 13 species and seven orders of birds) from the alcoholic collections of the American Museum of Natural History. These represented the work of a variety of collectors and collection dates. They were preserved in isopropyl alcohol at the time of examination, but without specific testing we cannot be certain if they were originally fixed in formalin; typical of biological collections, no treatment documentation exists.

\footnotetext{
${ }^{1}$ Received 3 August 1987. Final acceptance 24 November 1987.

${ }^{2}$ Present address: Biology Dept., Winthrop College, Rock Hill, SC 29733.
}

Our intent was to study gross anatomy and histology of the reproductive tract and to attempt to collect sperm from testes and vasa deferentia for ultrastructural study, but of the 13 specimens examined not one was suitable for detailed study. Decomposition of the reproductive tract and gonads had advanced such that, although some gross tissue organization was recognizable, histological analysis was not possible and no intact sperm were located.

The number of specimens we examined was too small to consider this an assessment of alcoholic collections. Moreover, the reproductive tract is known to decompose faster than many other internal systems (Bedford 1975), exaggerating any generalization of specimen damage (although an intact reproductive system probably guarantees that other systems have also been usefully preserved). Nevertheless, with histological studies particularly in mind, our negative findings reinforce a concern about the usefulness of many current alcoholic specimens. Extensive experience by one of us (Cannell) with another more robust internal system (the syrinx) reinforces this view, particularly with regard to larger specimens. It seems clear, at least, that the existence of an alcoholic specimen of a species does not necessarily equate with the availability for study of that species' internal anatomy. Hence, the figures indicated in The World Inventory of Avian Spirit Specimens (Wood et al. 1982) must unfortunately be viewed with caution.

\section{SPEED AND METHODS OF FIXATION}

Delay between death and fixation may be the most frequent cause of deteriorated tissue in existing alcoholic specimens, as has been noted by Berger (1955: $300)$ and others. Burton (1978:190) stated candidly that "fixation was often poor in many older specimens, and I suspect many are simply a surplus which the collector had no time to skin, and eventually crammed into an insufficient supply of spirit at the end of the day, after several hours decomposition and desiccation." Raikow (1985:114) also noted "the habit of collectors making study skins of the good specimens and anatomical specimens of the rest." To professional collectors, the value of anatomy may have seemed arcane relative to ornithology's traditional focus on plumage. 
Besides, any decay was internal and invisible. It may have been unfortunately easy to delay alcoholic specimen preparation in the face of often-difficult field conditions.

But, after death, lysozyme and macrophage activities rapidly cause disruption of membranes and destruction of tissues. This process is temperature related and proceeds quickly within a bird's warm internal environment. Fine structure of some systems, such as the reproductive tract, begins to deteriorate within minutes after death, and postmortem delay of a few to several hours results in widespread damage.

A fixative halts the decay process by coagulating cell contents into insoluble elements (Fink et al. 1978). Quay (1974), Burton (1978), and others have demonstrated that detailed histological analyses are possible on very old specimens whose original fixation was fast and thorough. We strongly reinforce recommendations that birds intended for alcoholic collections be fixed as soon as is possible after death.

Virtually all avian fluid specimens are currently fixed in formalin (a 10\% formaldehyde solution, Quay 1974) but many early specimens were fixed in other solutions (see Williams and Hawks 1987) or placed directly into alcohol (a good preservative but a poor fixative, see Raikow 1985). Although it may be pertinent or critical to a particular study, it is not easy for researchers to determine how or if a particular specimen has been fixed. It would be useful if museums could identify, through archival or experimental methods, those specimens fixed in solutions other than formalin.

The advantages of formalin, the standard museum fixative, have been discussed (e.g., Quay 1974, Fink et al. 1978), as have possible advantages of other fixatives, for example Bouin's solution, Gilson's solution, acidified formalin, acetic acid-formalin-alcohol, or glutaraldehyde. These other fixatives may have greater potency in coagulating tissue proteins or in facilitating staining by some histological dyes. Fink et al. (1978: 9) stated that: "other fixatives certainly have a role to play in modern ichthyological collections." The same may be true for collections of birds. Preparation of some specimens in alternative fixatives would increase research options, as long as these are suitably documented.

Methods of fixation also vary. Although Berger (1955), Quay (1974), Raikow (1985), and others have recommended perfusion of fixative into the bird's cardiovascular system, this procedure is rarely practiced by field collectors and its actual merits and practicality remain unclear. Quay (1974:95) said that an experienced preparator could perfuse a specimen within 3 to $5 \mathrm{~min}$. In the field, a longer period might be required; performed hurriedly perfusion itself might cause tissue damage, particularly to the circulatory system. The actual value of perfusion could be assessed by histological study of specimens with known treatments. If found to produce significantly better specimens, then perfusion should be learned and employed by field collectors. Otherwise, fixative should be injected into major muscles, body cavities, the brain, and the orbit as soon as possible after death (and after tissue samples have been removed for biochemical analysis), followed by detergent or alcohol wash and whole immersion in the fixative (see Cato 1986:26). Particular care should be given to larger specimens.

\section{SERIES}

Generally, museums have obtained series of skins and skeletons (see Johnson et al. 1984, Zink and Remsen 1986) but only "representative" alcoholic specimens (see Raikow 1985). This practice both reflects and has influenced directions of anatomical research in ornithology. For example, the current lack of alcoholic specimen series prohibits examination of geographic or intra- or interspecific variation (see McKitrick 1985, Raikow 1985), while the preservation state of many specimens apparently inhibits comparative histological analysis.

Even for traditional studies of representative specimens, series are important. As with other collection types, a specimen may be of an inappropriate age, sex, location, or season for a particular study, or features of interest may have been damaged during collection or preparation. For alcoholic specimens, there is the additional possibility (noted above) that structures have deteriorated due to delayed or inadequate fixation. Finally, structures may have been disrupted or removed during previous dissections. Alcoholic collections are unique among traditional preparation types in that examination usually damages the specimen. It is necessary to have long series to ensure that even a few representative specimens exist.

Depletion of specimens through repeated dissection is not currently a serious problem; anatomical study has not been in ornithological vogue for many decades. But research fashions do change; through time the number of anatomists and the sophistication of their techniques is likely to increase, while the availability of new and diverse specimen material seems certain to decline due to restrictive laws, diminished bird populations, and rising costs. Eventually, depletion of alcoholic specimen material may become one of the most significant problems facing ornithological museum scientists.

We argue that optimal field procedures include preservation of tissues and alcoholic specimens, especially for species rare in collections. Alcoholic specimens preserve all the information of skins and skeletons plus that of internal anatomy, stomach contents, sperm, etc. (but see Fry 1985 for cautions about possible absolute plumage color change). Skins and skeletons can always be prepared later if desirable, and under improved conditions. Even for common species, we suggest that one or two alcoholic specimens be prepared for each skeleton or skin. Of course, complete alcoholic body and flat skin preparations can be made from individual specimens, similar to combination skin and skeleton preparations urged by Johnson et al. (1984). Together with general augmentation of alcoholic collections, we urge that intermuseum usage guidelines and dissection request procedures be developed for all species currently rare in alcoholic collections.

\section{DOCUMENTATION OF TREATMENT HISTORY}

Preparation and treatment histories of biological specimens are not normally documented. This saves time, 
but at the cost of knowledge, severely limiting effective collection management. Without treatment histories, specific procedures and substances cannot be associated with resulting specimens, and hence cannot be evaluated. Additionally, specific fixing, preserving, and management procedures (e.g., freezing, perfusion, transfer between alcohol types, time between death and fixation, kind and concentration of fixative, previous dissections performed) may be of interest to some researchers. For example, exposure to alum, borax, or other alkaline components common in early fixatives may render specimens less useful for DNA analysis (Williams and Hawks 1987), while freezing renders specimens unsuitable for most histological or electron microscope study.

Conservators of art, historical, and anthropological collections routinely document the technical history of individual objects and have developed specific procedures for doing so (see Craft and Jones 1981). Their importance is emphasized in the section "Report of Treatment" in the American Institute for Conservation's Code of Ethics and Standards of Practice (Am. Inst. Conservation 1979). We believe that introduction of similar standardized procedures, documenting all aspects of a specimen's treatment history from collection on, would significantly advance biological collection methodology.

\section{CONSERVATORS IN BIOLOGICAL COLLECTIONS}

Biological collection management has tended to follow tradition, lacking frequent critical assessment (see, for example, Cato 1985). Meanwhile, sophisticated knowledge of materials and their effects has developed within art, historical, and anthropological collections. Object conservation is a career in itself, and most large collections in those fields employ a professional conservator. The study of conservation of biological materials is in its infancy (see, for example, Williams and Hawks 1987, for a useful initial survey), but much of the current expertise of art, historical, and anthropological conservators may also apply to biological collection management. The involvement of professional conservators in biological collection management, as general museum staff or consultants, is probably the mos important step (besides continued specimen collection) that natural history museums can take at this time to safeguard the quality of their collections in the long run (see Hawks and Rose 1987).

\section{CONCLUSIONS}

More than other taxonomic disciplines, ornithology is pervaded by a significant anticollecting attitude. Of traditional preparation types, alcoholic collections are the most severely limited such that many current and future research options are prohibited. Here, we argue the need to add properly fixed alcoholic material to ornithological collections, including representation of additional taxa and increased numbers of specimens per species.

Specific procedural recommendations are difficult to make without greater knowledge of the effects of traditional techniques and materials. Biological collection management compares unfavorably with procedures developed for art, historical, and anthropological col- lections. We urge that this gap be bridged, specifically through introduction of specimen treatment documentation and consultation with professional conservators.

The need for avian anatomical material and for collections support has been frequently expressed (e.g., Berger 1955, Raikow 1985, Nicholson 1986, Wilson 1986, Zink and Remsen 1986). By stressing quality of preparation and collection management procedures, we agree with recommendations of Johnson et al. (1984), Jenkinson and Wood (1985), and others who emphasize maximum utility of individual specimens. As the demand and sophistication of anatomists and histologists increase and as diverse specimen material becomes harder or impossible to procure, the quality of existing collections will gain importance and come under increased scrutiny. The augmentation and care of ornithological collections will, in the long run, almost certainly prove more valuable to ornithology than any current line of individual research.

Sydney Anderson, Al Gardner, Kimball Garrett, Gary Graves, Catharine Hawks, Marion Jenkinson, Carolyn Rose, Scott Wood, and Richard Zusi provided useful discussion and helpful comments on manuscript drafts; we are grateful to them. We thank George Barrowclough for access to materials at the American Museum of Natural History. We also acknowledge the Collections Committee of the American Ornithologists' Union for the valuable contribution they have made in the Anatomical Inventory series.

\section{LITERATURE CITED}

Am. Inst. Conservation. 1979. A.I.C. code of ethics and standards of practice, p. 10-23. In The A.I.C. directory. Am. Inst. Conservation, Washington, DC.

BEDFORD, J. M. 1975. Maturation, transport and fate of spermatazoa in the epididymis, p. 308-318. In R. O. Greep and E. B. Astwood [eds.], Handbook of physiology; Section 7: Endocrinology. Vol. V. Male reproductive system. American Physiology Society, Washington, DC.

Berger, A. J. 1955. Suggestions regarding alcoholic specimens and skeletons of birds. Auk 72:300303.

Burton, P.J.K. 1978. Studies on functional anatomy in birds utilizing museum specimens, p. 190-194. In R. Nöhring [ed.], Acta 17th Congr. Intern. Ornithol. Deutsche Ornithologen-Gesellschaft, Berlin.

CAto, P. S. 1986. Guidelines for managing bird collections. Texas Tech Univ. Press., Lubbock.

Craft, M., and S. Jones [EDS.]. 1981. Written documentation. Am. Inst. Conservation, Philadelphia.

Fink, W. L., K. E. Hartel, W. G. Saul, E. M. Koon, AND E. O. WILEY. 1978. A report on current supplies and practices used in curation of ichthyological collections. Am. Soc. Ichthyologists and Herpetologists, Washington, DC.

FRY, C. H. 1985. The effect of alcohol immersion on the plumage colours of bee-eaters. Bull. Br. Ornithol. Club 105:78-79. 
Hawks, C., AND C. Rose. [eDs.], 1987. A preliminary list of conservation resources for the care of natural history collections. Society for the Preservation of Natural History Collections, Nat. Mus. Nat. Hist., Smithsonian Inst., Washington, DC.

Jenkinson, M. A., AND D. S. Wood. 1985. Avian anatomical specimens: a geographical analysis of needs. Auk 102:587-599.

Johnson, N. K., R. M. Zink, G. F. BARrowclough, AND J. A. MARTEN. 1984. Suggested techniques for modern avian systematics. Wilson Bull. 96: 543-560.

McKitrick, M. C. 1985. Pelvic morphology of the kingbirds and their allies (Aves: Tyrannidae). Ann. Carnegie Mus. 54:275-317.

Nicholson, T. D. 1986. Systematics and museums. Science 231:442.

QUAY, W. B. 1974. Bird and mammal specimens in fluid-objectives and methods. Curator 17:91-104.

RAIKow, R. J. 1985. Museum collections, comparative anatomy and the study of phylogeny, p. 113121. In E. H. Miller [ed.], Museum collections: their roles and future in biological research. British Columbia Provincial Museum, Occas. Paper No. 25.

Williams, S. L., and C. A. Hawks. 1987. History of preparation materials used for Recent mammal specimens, p. 21-49. In H. Genoways, C. Jones, and O. Rossolimo [eds.]. Mammal collection management. Texas Tech Univ. Press, Lubbock.

Wilson, E. O. 1986. Time to revive systematics. Science 230:1227.

Wood, D. S., R. L. Zusi, ANd M. A. Jenkinson. 1982. World inventory of avian spirit specimens, 1982. American Ornithologists' Union and Oklahoma Biological Survey, Norman, OK.

Zink, R. M., AND J. V. RemSEN. 1986. Evolutionary processes and patterns of geographic variation in birds, p. 1-69. In R. F. Johnston [ed.], Current ornithology. Vol. 4. Plenum Press, New York.

Zusi, R. L., D. S. Wood, AND M. S. Jenkinson. 1982. Remarks on a world-wide inventory of avian anatomical specimens. Auk 99:740-757.

\title{
SCRUB JAY PREDATION ON STARLINGS AND SWALLOWS: ATTACK AND INTERSPECIFIC DEFENSE ${ }^{1}$
}

\author{
Paul R. Ehrlich and John F. McLaughlin \\ Department of Biological Sciences, Stanford University, Stanford, CA 94305
}

Key words: Aphelocoma coerulescens; Cliff Swallow; European Starling; interspecific defense; predation; Scrub Jay.

Jays are known to be important predators of both the eggs and nestlings of other birds, but attacks on adults or juveniles capable of competent flight are rarely reported. On the campus of Stanford University, Santa Clara County, California, a Scrub Jay (Aphelocoma coerulescens) was observed repeatedly attacking a juvenile European Starling (Sturnus vulgaris). When first observed, at 09:00 on 4 May 1987, the starling appeared disoriented. It flew at a height of about $1 \mathrm{~m}$ into the side of a building, dropped to the ground, but remained active. The pursuing jay immediately cornered the starling and pinned it to the ground with its feet. While leaning away from the starling to avoid jabs of

\footnotetext{
${ }^{\prime}$ Received 17 August 1987. Final acceptance 4 December 1987.
}

its bill, the jay repeatedly pecked vigorously at the starling's head and shoulders with its bill. The sequence was interrupted by the intervention of an adult starling which chased the jay away from the juvenile, but the jay then returned and pursued the flying juvenile, catching it twice, pinning it as before, and hammering at it until the adult starling intervened each time. Groups of students interrupted the attack and all three birds disappeared. The entire sequence probably took less than $1 \mathrm{~min}$.

In a location about $50 \mathrm{~m}$ away on 8 May 1987 a second predatory interaction was observed. The behavior of the jay and the juvenile starling was similar; the starling's flight seemed clumsy, but it was impossible to determine whether this was because of its inexperience or a result of injury. In this case two or three Brown Towhees (Pipilo fuscus) intervened and temporarily drove off the jay. It returned to resume the attack, however, until an adult starling flew down from an adjacent live oak tree (Quercus agrifolia) and attacked the jay. The juvenile weakly flew several meters and was again pinned by the jay. The adult starling 